\title{
Die owerheid se ingesteldheid ten opsigte van godsdiens: Die geskiktheid van die aktief-plurale opsie vir die toepassing van artikel $\mathbf{3 6}$ van die Nederlandse Geloofsbelydenis
}

\begin{abstract}
Author:
D. Francois Muller ${ }^{1}$

Affiliations:

${ }^{1}$ Unit for Reformed Theology, North-West University, Potchefstroom Campus, South Africa

Correspondence to: Francois Muller

Email:

10075798@nwu.ac.za

Postal address: PO Box 20004, Noordbrug 2522, South Africa

Dates:

Received: 07 Mar. 2011 Accepted: 15 June 2011 Published: 02 Nov. 2012

How to cite this article: Muller, D.F., 2012, 'Die owerheid se ingesteldheid ten opsigte van godsdiens: Die geskiktheid van die aktief-plurale opsie vir die toepassing van artikel 36 van die Nederlandse Geloofsbelydenis', In die Skriflig/In Luce Verbi 46(1), Art. \#37, 11 pages. http:// dx.doi.org/10.4102/ids. v46i1.37
\end{abstract}

(C) 2012. The Authors. Licensee: AOSIS OpenJournals. This work is licensed under the Creative Commons Attribution License.
'Wat behoort 'n owerheid se ingesteldheid ten opsigte van godsdiens te wees?' is 'n vraagstuk waarvoor owerhede millennia lank reeds staan en wat tans al meer akuut word. J.M. Vorster het vyf opsies geïdentifiseer wat owerhede se ingesteldheid vergestalt en verkies die sogenaamde 'aktief-plurale' opsie. Hiervolgens behoort owerhede alle godsdienste en/of tradisies toe te laat en geeneen in besonder te bevoordeel nie. Artikel 36 van die Nederlandse Geloofsbelydenis (1561) verteenwoordig 'n vername verwoording van waartoe die Reformatoriese tradisie glo owerhede geroep word. Hierdie studie het dus die geskiktheid van die aktief-plurale opsie vir die toepassing van artikel 36 ondersoek. Die fokus van die ondersoek was op die agtergrond waarbinne en die doel waarmee die belydenis geformuleer is; die belangrikste tekstuele veranderinge $(1905,1982)$; asook die korrekte betekenis van artikel 36. Daar is vir lank gemeen dat owerhede onder meer die taak het om alle afgodery en valse godsdiens uit te roei. Sedert 1982 word bely dat owerhede (slegs) die verkondiging van die Evangelie moet beskerm om hierdie doelwitte sodoende te bereik. Alle owerhede ontvang hulle gesag van God en moet sy getroue dienaars wees - sonder om 'n dienaar van enige kerk en/of tradisie te word.

Government's attitude towards religion: the suitability of the active-plural option for the implementation of article 36 of the Belgic Confession. 'What attitude should a government have towards religion?' was not only a question that governments had struggled with for ages, but one currently growing in significance. J.M. Vorster identified five options that different governments had chosen and he selected the so-called 'active-plural option' as his preference. This option allowed governments to make provision for all religions or traditions, without the promotion of any specific one. Article 36 of the Belgic Confession (1561) represents a foremost statement of what the Reformed tradition believed governments were being called to. This study therefore investigated the suitability of the 'active-neutral option' for the implementation of article 36. This was done while exploring the specific circumstances within and goal with which the confession was formulated; the most important changes to the text of article 36 $(1905,1982)$ as well as its corrected meaning. Whereas there was a time when governments were seemed to have the task to, amongst others, destroy all idolatry and false worship, it was stated in 1982 that governments (only) had to protect the proclamation of the Gospel and in so doing achieved this destruction. All governments received their authority from God and were to be his faithful servants - without becoming servants of any church and/or tradition.

\section{Voorwoord}

Ek is een van verskeie wat die voorreg gehad het om my nagraadse studie onder leiding van prof. J.M. Vorster, aan wie hierdie feesuitgawe opgedra word, te voltooi. Hoewel ek nooit in my voorgraadse jare by hom klas gehad het nie, was hy een van die sprekers tydens ons jaargroep se promosieplegtigheid. Nadat een van die ander sprekers ons deeglik gewaarsku het hoeveel harde werk in die bediening op ons wag, het prof. Vorster aan die beurt gekom. Hy het van sy voorbereide toespraak afgewyk om ons mee te deel dat die bediening vir hom elke dag 'n vreugde was. Oor die jare heen het ek besef dat hierdie terloopse opmerking veel van sy ingesteldheid openbaar. Hoewel hy stewig in die Reformatoriese tradisie gevestig is, het hy die vermoë om sake met ' $n$ vars uitkyk te benader. My bede is dat hy eendag, wanneer sy formele loopbaan tot 'n einde kom, steeds sal kan terugkyk en sê: 'Wat 'n vreugde!'.

Dit is dus my voorreg om in hierdie artikel vervolgens die fokus te plaas op 'n kwessie wat prof. Vorster ondersoek het, naamlik owerhede se ingesteldheid ten opsigte van godsdiens. In 
die ondersoek maak ek ruim gebruik van die proefskrif wat ek pas onder sy leiding voltooi het: 'Die roeping van SuidAfrikaanse owerhede binne die grondwetlike demokrasie in die lig van artikel 36 van die Nederlandse Geloofsbelydenis'.

\section{Inleiding}

\section{Aktualiteit}

Die mens is ten diepste 'n religieuse wese (Van der Walt 2002:171). Gevolglik het owerhede voortdurend te kampe met die vraag wat hulle ingesteldheid ten opsigte van godsdiens behoort te wees. Die geskiedenis van owerhede is nie alleen besaai met godsdienstige kwessies nie, maar ook bevlek met eindelose voorbeelde van geweld wat in die naam van godsdiens gepleeg is. Die 16de eeuse Europa is immers beroemd vir die Reformasie én berug vir talle godsdiensoorloë (vgl. Van der Zwaag 1999:32).

Tans is die konflik tussen godsdienste aan die toeneem (vgl. Sauer 2009:70, 73). Vergelyk die konflik tussen Moslems en Christene in Afrika onder andere in Nigerië (Ban 2008) en Darfur (Smiles 2008:59); die konflik waarin Moslemgemeenskappe binne tradisioneel Westerse lande hulleself toenemend bevind en die gepaardgaande kontroversie ten opsigte van kleredrag en die posisie van vroue (Ozyurt 2009). ${ }^{1}$ Grim (2010:40) bereken dat 70\% van die wêreld se bevolking in lande leef waar owerhede streng of baie streng beperkinge ten opsigte van godsdiens het en dat hierdie beperkinge veral vir godsdienstige minderheidsgroepe geld. Venter (2007:1193) wys daarop dat owerhede toenemend politieke besluite (ten opsigte van byvoorbeeld onderwys, kriminele vervolging, die keuse van openbare vakansiedae) moet neem wat burgers se godsdienstige oortuiginge raak. In 'n globaliserende wêreld word owerhede voor al hoe dringender uitdagings gestel en word die vraag na watter ingesteldheid ' $n$ owerheid ten opsigte van godsdiens moet hê, al hoe meer akuut.

In die opvolg van sy publikasie Christian attitude in the South African liberal democracy (2007:149-167), bespreek Vorster (2010:153) die ingesteldheid wat owerhede ten opsigte van godsdiens inneem aan die hand van vyf opsies: die aktiefteokratiese opsie; aktiewe staatsgodsdiens-opsie; aktiefneutrale opsie; aktief-universalistiese opsie sowel as die aktief-plurale opsie. Volgens Vorster (2010:173, 2007:166) is laasgenoemde die eties mees aanvaarbare. ${ }^{2}$

Die Nederlandse Geloofsbelydenis (NGB) is een van verskeie belydenisse wat tydens die Reformasie geformuleer is (Doekes 1975:33; Van der Zwaag 1999:129). Die NGB kom uit die hart van die Reformasie en gee in artikel 36 aandag aan owerhede

1.In die lig van die opstande wat in die begin van 2011 in Tunisië, Egipte, Libië en sekere state in die Persiese Golf uitgebreek het, wys Scholtz (2011) daarop dat daar ' $n$ groter behoefte aan liberale demokrasie in die Arabiese (Moslem-) state is as wat waarnemers tot onlangs vermoed het en dat die invloed van religieuse fundamentalisme aan die afneem is. Hierdie nuwe perspektief mag mettertyd ' nuwe beoordeling vereis.

2.Vorster (2010:155-162) verkies hierdie opsie aangesien dit na sy mening die beste voldoen aan die perspektief wat die Bybel (Ou én Nuwe Testament) bied op teokrasie; op die plig van gelowiges 'teenoor alle mense' sowel as op die roeping van owerhede. Tesame hiermee bied hierdie opsie, in vergelyking met die ander van owerhede. na sy mening ook optimale godsdiensvryheid (Vorster 2010:172). Vergelyk ook paragraaf 4.6-4.8 hieronder wat die saak verder bespreek. se roeping en take, in besonder ten opsigte van godsdiens. Hierdie belydenis is in 1561 openbaar gemaak en tydens die sinode van Dordrecht (1618/1619), waar afgevaardigdes van oor die hele Protestantse wêreld teenwoordig was, as een van die Formuliere van eenheid aanvaar. Hoewel die NGB vanjaar dus 450 jaar oud is, word dit steeds as een van die vernaamste belydenisskrifte van kerke in die Reformatoriese tradisie aanvaar, ook in Suid-Afrika.

\section{Probleemstelling}

Hierdie navorsing stel gevolglik ondersoek in na die toepasbaarheid van NGB artikel 36 binne 'n omgewing waar die owerheid se ingesteldheid ten opsigte van godsdiens aan die hand van die aktief-plurale opsie beskryf kan word. Die ondersoek word hoofsaaklik binne die SuidAfrikaanse demokratiese konteks gedoen. Let daarop dat die Reformatoriese tradisie 'n beduidende bydrae tot die wêreldwye vestiging van demokrasie as konsep en regeringstelsel gelewer het (Witte 2009). Artikel 36 is dus nie alleen van belang vir die aanhangers van hierdie tradisie nie, maar behoort in werklikheid veel wyer aandag te geniet.

Daar is egter 'n dilemma wat die bewoording van artikel 36 betref, aangesien daar nie meer net een algemeen aanvaarde weergawe van die teks van die artikel bestaan nie. Met verloop van tyd het verskeie kerkverbande verskillende veranderinge aan die teks aangebring. ${ }^{3}$

Die vraag is gevolglik nie alleen wat in artikel 36 bely word nie, maar ook watter weergawe ter sprake is. Die Reformatoriese kerke in Suid-Afrika erken tans die weergawe soos aanvaar in 1982. ${ }^{4}$ Die veranderinge wat wêreldwyd aan die teks aangebring is, is nie kosmeties nie, maar het telkens saamgehang met die betrokke gemeenskap se oortuiging oor wat ten opsigte van die owerheid bely behoort te word. In sekere gevalle is die veranderinge onder dwang van die owerhede aangebring.

\section{Argumentasielyn}

Gevolglik word eerstens gefokus op artikel 36, in besonder na sy 'Suid-Afrikaanse' weergawes om aan te dui waartoe owerhede geroep word. (Die plig wat hierdie artikel op elke burger lê, sal dus net waar van toepassing bespreek word.) Hierna word ondersoek ingestel na die aktief-plurale opsie en die geskiktheid daarvan vir die toepassing van artikel 36 binne die Suid-Afrikaanse konstitusionele demokrasie.

\section{Artikel 36 van die Nederlandse Geloofsbelydenis}

Hoewel elke historiese dokument vanuit sy konteks geïnterpreteer moet word, merk Van der Zwaag (1999:99)

3.Vergelyk die volgende voorbeelde: die Gereformeerde Kerken in Nederland in 1905 (Van der Zwaag 1999:333); die Free Church of Scotland in 1910 (Free Church of Scotland 2011); die Christian Reformed Church of North America in 1910, 1938 en 1958 (Christian Reformed Church of North America 2011) en die Gereformeerde Kerke in Suid-Afrika in 1982 (GKSA 1982:386, 409).

4.Behalwe waar anders aangetoon, sal ek voortaan na hierdie weergawe verwys 
tereg op dat dit in besonder van die NGB geld en soveel te meer van artikel 36. Muller $(2010: 72,74)$ argumenteer dat artikel 36, gesien teen die agtergrond waarbinne dit ontstaan het en ten minste in sover De Brès dit as verweerskrif aangewend het, inderwaarheid die fokuspunt van die NGB vorm.

\section{Die omstandighede waarbinne die NGB, in besonder artikel 36, geformuleer is}

Guido de Brès het 'n dokument, wat later die NGB sou word, as 'n uiteensetting van die gereformeerde geloof opgestel. Hiermee wou hy die gereformeerdes onderskei van die Anabaptiste en aantoon dat eersgenoemde ten onregte vervolg is. Die Rooms-Katoliekgesinde owerhede het beide groepe vervolg, soms met uiterste geweld (vgl. Walker et al., 1997:516; De Jong 1987:221; Latourette 1953:763; Kurtz 1904:234). ${ }^{5}$ Die vervolging het voortgespruit uit hierdie owerhede se kontra-Reformatoriese pogings om die Roomse godsdiens te verdedig of te hervestig in gebiede waar Lutherse, Gereformeerde en Anabaptistiese groepe inslag gevind het. Hierdie pogings moes die verbrokkeling van die corpus Christianum, wat in wese ' $n$ godsdiensstaat was, teenwerk nadat dié ryk begin het om op grond van die beginsel van cuius regio, eius religio (Whose realm, his religion) ${ }^{6}$ in verskillende landskerke uiteen te val. Op daardie stadium het kerk en owerheid al vir eeue 'n baie noue verhouding gehad en was die moderne gedagte van 'n skeiding van kerk en staat 'n anachronisme. Godsdiens en politiek kon beswaarlik geskei word (vgl. Van der Zwaag 1999:32).

Die Anabaptiste (en die gereformeerdes) is gevolglik nie alleen as ketters beskou nie, maar ook as staatsgevaarlike revolusionêre wat die bestaande orde wou omverwerp. Hoewel die Anabaptiste uit verskeie groepe bestaan het en almal nie oor dieselfde kam geskeer kan word nie (Muller 2010:31), het die meeste van hierdie groepe onder meer geweier om militêre diens te verrig, belasting aan 'n aardse heerser te betaal of om ' $n$ eed van getrouheid aan so iemand af te lê (Walker et al. 1997:449). Geen owerheid sou dit verdra nie. Boonop het tragiese voorvalle soos dié by Münster die vervolging van Anabaptiste gesanksioneer. Deur te weier om kinders te doop, is die (Rooms-Katolieke) kerk se houvas ook beperk aangesien 'n ongedoopte nie 'n lidmaat was nie.

Hoewel die Gereformeerdes die Reformasie uiteraard ten volle ondersteun het, was hulle geheel en al teen die Anabaptiste gekant, op beide godsdienstige en politieke gebied. Die Gereformeerdes het gemeen dat die Anabaptiste die vooruitgang van die Reformasie bedreig het (Cloete 1986:81-90). Die Gereformeerdes wou inderwaarheid goeie

5.Volgens Kurtz (1904:247) het die Hertog van Alva met sy vertrek vanuit die Nederlande in 1573 daarop geroem dat hy by die 18000 mense weens oproer of as gevolg van hulle geloof na die beuels gestuur het. Hy het alle Nederlanders as skuldig beskou omdat die een helfte aan die oproerigheid sou deelgeneem het en die ander helfte hulle dit nie belet het nie.

6. Hierdie beginsel is in 1555 formeel tydens die Vrede van Augsburg aanvaar. De Jong $(1980: 207)$ wys daarop dat die ooreenkoms eintlik nog net vir die Lutherane wat die Augsburgse konfessie aanvaar het, ware godsdiensvryheid gebring het. Die wat die Augsburgse konfessie aanvaar het, ware godsdiensvryheid gebring het. Die
gereformeerdes (soos die Zwingliane) en die Anabaptiste het op daardie stadium nog nie eens gewetensvryheid geniet nie.
Katolieke wees (vgl. NGB 1992 [art. 27]) en die owerhede gehoorsaam in ooreenstemming met die opdragte in die Bybel (vgl. Romeine 13:1-7 in die lig van NGB art. 7).

Tesame met die erkenning dat niemand hom van die ware kerk mog afgeskei het nie (NGB art. 28), het De Brès vervolgens in artikel 36 beklemtoon hoe belangrik hierdie gehoorsaamheid is (my beklemtoning):

Verder is elkeen verplig, van watter hoedanigheid, rang of stand hy ook al mag wees, om hom aan die owerhede te onderwerp, belasting te betaal, aan hulle eer en onderdanigheid te bewys, hulle te gehoorsaam in alles wat nie met die Woord van God in stryd is nie ... Hierin verfoei ons die Wederdopers ${ }^{7}$ en ander oproerige mense en in die algemeen almal wat die owerheidsgesag en die regeerders wil verwerp en die regsorde omver wil stoot ... (NGB 1992:514)

Hoewel die NGB 'n algemene uiteensetting van die gereformeerde geloof is en ook as sodanig deur die sinode van Dordrecht aanvaar is, het De Brès die verskille met die Anabaptiste dus beklemtoon, en ten koste van die verskille met die Rooms-Katolieke (Muller 2010:68).

\section{Die plek en belang van artikel 36 binne die NGB}

Die NGB bestaan uit 37 artikels. Hierdie artikels kan op verskeie maniere gegroepeer word (vgl. Jonker 1994:53-55; Polman s.a. a:108; Van Bruggen 1980:16). Die indeling volg die indeling van die Confessio Gallicana op die spoor van die Institusie van Calvyn (Strauss 1993:506). Enkele jare voordat De Brès die NGB bekendgestel het, het Calvyn hom aangeraai om voort te gaan om die Gallicana te gebruik. Muller (2010:36) bespreek die politieke redes waarom De Brès die NGB in weerwil van die advies bekendgestel het (vgl. ook Doekes 1975:55). Uit 'n godsdienstige oogpunt gesien het die Gallicana nie die verskille met die Anabaptiste genoeg beklemtoon nie (vgl. Schulze 1991:32, 35).

Soos vermeld, vorm artikel 36 'n fokuspunt van die NGB en saam met artikel 37 'n klimaktiese slot in De Brès se verweer. Let daarop dat artikel 36 en 37 oorspronklik 'n dubbele slot vir die NGB gevorm het, waarvolgens artikel 36 as 'n appèl op die aardse owerheid en artikel 37 as 'n appèl op die hemelse gedien het (Muller 2010:59; Vonk 1956:549).

\section{Die struktuur van artikel 36}

Artikel 36 het ' $n$ afgeronde struktuur. Die teks soos aanvaar in 1619 bestaan uit vyf sinne waarin gefokus word op:

- God se instelling van die owerheid en sy motief daarvoor.

- Die middele wat God die owerheid gee om sy taak te kan uitvoer.

- Die taak van die owerheid, ook ten opsigte van die godsdiens, en die doel waarmee die owerheid sy taak moet uitvoer.

- Die verpligting ten opsigte van die owerheid.

- Die gevolglike verfoeiing van die Anabaptiste en/of oproeriges.

7.Hoewel die saak in De Brès se oorspronklike teks na vore kom, is die uitdruklike verwysing na die Wederdopers eers 'n paar jaar later ingevoeg (Muller 2010:36; Vonk 1956:646). 


\section{'n Oorsig oor die veranderinge aan die teks van artikel 36}

Teen die tyd dat die NGB in 1619 as een van die Formuliere van eenheid aanvaar is, is daar al verskeie veranderinge aan die teks aangebring (vgl. Muller 2010:58; Vonk 1956:649655). Nie een hiervan het soveel kontroversie ontlok as die verandering wat in 1905 in Nederland aan die derde sin (van die oorspronklike teks) aangebring is nie. Hiervolgens het die sinode van die Gereformeerde Kerken, by gebrek aan 'n beter oplossing, die woorde 'om te weren en uit te roeien alle afgoderij en valschen godsdienst, om het rijk des Antichrists te gronde te werpen' as deel van die plig van die owerheid geskrap (Muller 2010:96-101; vgl. ook Van der Zwaag 1999 wat hom in sy uiters omvattende werk op hierdie verandering toespits). Hierop was daar 'n versoek in die GKSA om artikel 36 in ooreenstemming aan te pas (GKSA 1910:43). Verskeie sinodes het die saak deeglik ondersoek en daarteen besluit. Muller (2010:129-141) bespreek die verloop van die saak.

Dit het gelyk asof die saak na dekades finaal besleg is totdat prof. D.C.S. van der Merwe oortuigend aangetoon het dat die Afrikaanse teks verkeerd vertaal is (vgl. Van der Merwe 1969:1-64; GKSA 1973:191-193; GKSA 1979:478; Visscher 1939:152; Heyns 1992:398). Gevolglik het die sinode van 1982 'n nuwe vertaling wat in samewerking met die Nederduitse Gereformeerde Kerk en Nederduitsch Hervormde Kerk gemaak is, aanvaar. Ten spyte van die sinode se besluit dat die nuwe vertaling nié 'n gewysigde betekenis aan die artikel geheg het nie, het die nuwe vertaling tog die betekenis van die artikel verander (vgl. Vorster 1993:314; Jonker 1994:84; Fourie 2006:160). ${ }^{8}$ In 2009 was daar weereens 'n beswaar teen die bewoording van die artikel. Die beswaar is egter nie gehandhaaf nie (GKSA 2009:674-687).

Voor 1982 het die teks soos volg gelui:

En hulle amp is om nie alleen ag te gee op en te waak oor die burgerlike regering nie, maar ook om die hand te hou aan die heilige Kerkdiens, om te weer en uit te roei alle afgodery en valse godsdiens, om die ryk van die antichris te gronde te rig en die Koninkryk van Jesus Christus te bevorder, die Woord van die Evangelie orals te laat preek, sodat God deur elkeen geëer en gedien word soos Hy in sy Woord beveel. (GKSA 1970:404)

Indien hipoteties gevra sou word: 'Het Guido de Brès destyds in artikel 36 bedoel dat owerhede self afgodsdienaars aktief moes beveg (in uiterste gevalle met geweld en met gebruik van diskresie) en wat is die hedendaagse oordeel oor sy standpunt?', sou die GKSA voor 1982 eerstens geantwoord het dat hy dit inderdaad bedoel het. De Brès was boonop ook korrek hierin vir solank as wat toerekeningsvatbaarheid in ag geneem is. Hierdie standpunt is in ooreenstemming met dié wat A.D.R. Polman stel in sy omvattende kommentaar op die NGB (vgl. Muller 2010:111, 152).

Sedert 1982 lui die bewoording (my beklemtoning):

En dit is nie alleen hulle taak om aan die staatsbestuur aandag te gee en daaroor te waak nie, maar ook om die heilige

8.Muller (2010:154) bespreek die rol wat die uitgangspunt dat die belydenis as in ooreenstemming met die Bybel aanvaar word, gespeel het in die redenasie van die sinode.
Woordbediening te beskerm, om sodoende alle afgodery en valse godsdiens teen te gaan en uit te roei, die ryk van die antichris te vernietig en die koninkryk van Jesus Christus te bevorder, die Woord van die evangelie orals te laat verkondig, sodat God deur elkeen geëer en gedien word soos Hy in sy Woord beveel. (GKSA 1982:386, 409)

Deur 'sodoende' in te voeg, het die sinode dit duidelik gemaak dat die kontroversiële frases ${ }^{9}$ nié, soos tot voor 1982 hanteer, op take van die owerheid dui nie, maar op die doel waarmee die owerheid sy besondere taak ten opsigte van die Woordbediening moet nakom.

Indien dieselfde hipotetiese vraag as hierbo gestel word, sal die antwoord nou eerder wees: 'Nee. Dit was nooit De Brès se bedoeling nie. Indien hy dit so bedoel het, sou hy boonop gefouteer het. Daarom moes die weergawe van voor 1982 verander word om misverstand te voorkom' (vgl. Muller 2010:152). Die jongste bewoording beperk dus die taak van die owerheid asook die gebruik van die swaardmag wat God hom gegee het tot die doel waarvoor God dit gegee het. Die owerheid het wel 'n plig ten opsigte van die godsdiens, maar slegs in dié sin dat die owerheid die kerk die ruimte en geleentheid moet bied om die Woord te kan verkondig.

\section{Uitgangspunte van artikel 36 wat in ag geneem moet word}

Ter wille van die korrekte toepassing van artikel 36 is dit noodsaaklik om met die volgende uitgangspunte van die artikel rekening te hou.

\section{Uitgangspunt: Gód het owerhede ingestel}

Anders as wat vandag algemeen aanvaar word, spruit die bestaan van owerhede nie uit 'n sekulêre sosiale kontrak of 'n sosiaal-evolusionêre proses nie (vgl. Bredenkamp 1996:103). Artikel 36 gaan daarvan uit dat Gód owerhede ingestel het. Hierdie feit bring 'n dubbele verpligting mee. Enersyds moet owerhede as dienaars van God gehoorsaam word (Rom 13:1). Andersyds moet owerhede hulle verantwoordelikheid voor God besef en erken (vgl. Johannes 19:11). In die lig van die talle wandade wat al in die naam van 'diens aan God' gepleeg is, sal sodanige erkenning nie noodwendig magsmisbruik voorkom nie. Die erkenning dat gesag van God af kom is egter die eerste, noodsaaklike stap in die proses om gesag in verantwoordelikheid teenoor Hom te gebruik. Calvyn (1992:1825) het daarop gewys dat Christus mense in owerheidsposisies gode noem. Gevolglik moet owerhede God in hulle ampte dien (Calvyn 1992 [Institusie IV.20.4.5-12]).

\section{Uitgangspunt: God het 'n spesifieke motivering vir die instel van owerhede}

Teenoor die humanistiese gedagte dat die mens ten diepste goed is, gaan artikel 36 uit van die verdorwenheid van die mens (vgl. NGB 1992:496 [art. 14]). Dit is juis vanweë hierdie verdorwenheid dat God in sý goedheid owerhede ingestel het. Hy wil gevolglik hê 'dat die wêreld deur middel van wette en regerings geregeer moet word, sodat die losbandigheid van die mense in bedwang gehou kan word en alles onder die mense ordelik kan verloop' (my beklemtoning).

9.'[A]lle afgodery en valse godsdiens teen te gaan en uit te roei, die ryk van die antichris te vernietig'. 
Owerhede moet dus toesien dat daar oor die algemeen reg en geregtigheid geskied. (Die eerste sin van artikel 36 laat reeds iets deurskemer van 'n onderskeid tussen 'n (owerheids-) persóón en sy mag of gesag - vergelyk: wette en regerings. Die feit dat Gód owerhede ingestel het, gee geen owerheid dus die reg om eiesinnig wette te maak en op goddelike sanksie aanspraak te maak nie.)

\section{Uitgangspunt: Daar is net een ware godsdiens en een egte vorm daarvan}

Artikel 36 gaan daarvan uit dat daar net een ware godsdiens (die Christelike) is en net een egte vorm daarvan (vgl. NGB 1992:507 [art. 29]). Verder is daar 'n besliste onderskeid tussen die ware en valse kerk. Artikel 36 neem hier dus 'n eksklusiewe standpunt in wat geen ruimte vir relativisme laat nie.

\section{Uitgangspunt: Élkeen is verplíg om God te dien}

Artikel 36 gaan daarvan uit dat die Drie-enige God die enigste God (NGB 1992:488, 491 [art.1 en 8]) is en daarom deur almal gedien moet word (vgl. 'sodat God deur elkeen geëer en gedien word soos Hy in sy Woord beveel'). Voor God het geen mens die reg om te weier om Hom te dien nie. Die wêreldlike owerheid het egter nie die reg, plig of vermoë om iemand wetlik (met die swaard) hiertoe te dwing nie. Mense moet deur Woordverkondiging en (geestelike) tug hiertoe gebring word. Toerekeningsvatbaarheid speel 'n kardinale rol. Enersyds kan daar nie noodwendig van enige persoon wat in 'n wêreldlike gesagsposisie is, verwag word om te bepaal wie die ware God is, wié Hom reg dien en wie nié. Hiermee saam behoort niemand gedwing te word om die Here te aanbid aangesien dit op die korttermyn huigelary in die hand werk en valse godsdiens en afgodery op die lang duur. ${ }^{10}$

As dienaar van God het elke owerheid gevolglik die plig om die ware kerk by te staan. Die kernvraag is egter hoe 'n owerheid dit moet doen.

\section{Voorlopige konklusie: Die roeping wat in artikel 36 op owerhede gelê word}

Daar is vir baie jare geredeneer dat artikel 36 dit aan die owerheid opdra om orde in die openbare lewe te handhaaf, ook ten opsigte van die godsdiens waar die owerheid valse godsdiens aktief moes teenstaan. Die betekenis wat die GKSA tot en met 1982 aan artikel 36 geheg het, was ook in ooreenstemming hiermee. Sedert die wysiging in 1982 is dit duidelik dat die owerheid nie die taak het om valse godsdiens eiehandig en desnoods met geweld te beveg nie, maar om die ruimte te skep waarbinne die kerk die Woord kan verkondig om valse godsdiens sodoende uit te roei. Die taak om die Woordbediening te beskerm, maak ' $n$ besondere deel uit van die owerheid se roeping om daartoe by te dra dat God deur elkeen gedien en eer sal word soos Hy in sy Woord beveel.

10.De Groot (1955:176) wys daarop dat Phillippe du Plessis Mornay gemeen het dat as iemand met geweld of selfs net kunsmatig gedwing word om gereformeerd te wees, huigelary bevorder word. Du Plessis Mornay het ' $n$ kardinale rol gespeel in die opstel van die Edik van Nantes (1598) wat godsdiensvryheid vir die Franse in die opstel van die Edik van Nantes (1598) wat godsdiensvryheid vir die Franse
Hugenote gewaarborg het. Dit is moontlik dat hy ook die opsteller van die Vindiciae Hugenote gewaarborg het. Dit is moontlik dat hy ook die opste
Contra Tyrannos (1579) kon gewees het (vgl. Laursen 1995:3).

\section{Slaggate in die interpretasie van artikel 36}

\section{'[A]fgodery, valse godsdiens en die ryk van die antichris'}

Op die oog af verwys hierdie frase na énige afgodery en valse godsdiens. Gesien in die lig van die omstandighede waarin die NGB aanvaar is, verwys 'afgodery en valse godsdiens' hier egter primêr na die Rooms-Katolieke vervalsing van die ware godsdiens (vgl. ook Polman s.a. b:286; Vonk 1956:638). Die fokus val dus nie hier op elkeen wat nalaat om die ware God op die egte wyse te aanbid of op die sisteme wat sulke mense onderhou nie. ${ }^{11}$

\section{'[N]ie alleen, maar ook' en 'sodat God deur elkeen geëer word'}

In die toepassing van artikel 36 is dit noodsaaklik om die (juridiese) taak van die owerheid en die taak van kerk te onderskei sonder om die oorkoepelende (etiese) doelwit waarmee God beide roep, te skei. Anders as in 'n sekulêre wêreld waar daar in terme van 'n streng skeiding van kerk en staat geredeneer word (vgl. die verwysing na die VSA en Frankryk hieronder), word daar in artikel 36 uitdruklik bely dat'n owerheid (en die kerk) sy take moet uitvoer 'sodat God gedien en geëer word soos Hy in sy Woord beveel'. Hier is dus geen sprake van 'n neutrale owerheid asof 'n owerheid niks met godsdiens te make moet of ma g hê nie. Wanneer die owerheid egter begin om take wat die Here op die kerk lê, op homself te neem en byvoorbeeld begin om afgodsdienaars wetlik te vervolg, vergryp so 'n owerheid hom aan 'n taak wat die Here op die kerk gelê het en misbruik hy die middele wat die Here vir hom gegee het om sy taak om orde te handhaaf, uit te voer. ${ }^{12}$ Daar sal hieronder weer aandag gegee word aan die noodsaak om te onderskei tussen die juridiese en etiese aspekte van 'n owerheid se verpligtinge.

11.Muller (2010:158-160) beredeneer hierdie kwessie soos volg: "Wat artikel 36 betref, is die kernprobleem egter of die klem hier op alle afgodery of op alle afgodery val. Gaan dit hier oor die afgodery wat byvoorbeeld deur die Moslems, Hindoes en sulke groepe bedryf word? Of gaan dit hier oor die afgodery wat die Rooms-Katolieke bedryf het in die sin dat die Mis byvoorbeeld in die Heidelbergse Rooms-Katolieke bedryf het in die sin dat die Mis byvoorbeeld in die Heidelbergse
Kategismus (Sondag 30, vraag en antwoord 80 ) 'n vervloekte afgodery genoem word. Wat presies moet dus teengestaan en uitgeroei word? Aangesien die hele word. Wat presies moet dus teengestaan en uitgeroei word? Aangesien
fokus van die belydenis die onderskeid tussen die ware en valse vorm van die Christelike geloof is, glo ek dat artikel 36 hier veral op die Rooms-Katolieke fokus en nié op alle afgodediens in die algemeen nie. Let dan ook daarop dat hier nie sprake is van afgodediens nie, maar van afgodery en valse godsdiens. Die Rooms-Katolieke is steeds as Christene beskou, maar as Christene wat afgodery bedryf en die Here op ' $n$ valse manier gedien het. Hierdie verklaring pas ook in by die kwessie van toerekeningsvatbaarheid ... Volgens die beginsel kon daar veel strenger opgetree word teen afvallige Christene van wie verwag kon word om die Here reg te dien, as teen mense wat die Here nog glad nie eens ken nie. Om laasgenoemdes nou (selfs met die swaard) aan te val om hulle van die Here se liefde vir hulle (Joh 3:16) te oortuig, sal tog nie deug nie. Ten slotte kan op die Heidelbergse Kategismus se omskrywing van afgodery gewys word (vgl. vraag en antwoord 95). Daar word eers gepraat van 'naas' en dan van 'in die plek van' - eers van Christene wat naas die gepraat van "naas en dan wan in die vertrou asof dit God is ... Hoewel die Reformatore die pous soms as die antichris gesien het (vgl. Institusie IV. 7.25), was dit nie konsekwent die geval nie (vgl. Institusie III. 20.42) en is die antichris ten diepste gesien as ' $n$ verwysing na die satan as teenstander van Christus. Johannes waarsku egter dat die antichris se valse profete uit die midde van die kerk sal voortkom (1 Joh 2:18-19). In hierdie lig gesien, asook in die konteks van die NGB verwys antichris hier in artikel 36 na die Roomse pous - nie soseer in sy persoon nie, maar sy amp. Die pous was die leier van die valse kerk soseer in sy peroon 29]). (vgl. NGB 1992 [art. 29]). Let egter op dat hier nie bely word dat die antichris self vernietig moet word nie, maar wel sy ryk. Dit is net Christus wat die mag en gesag
het om die antichris self te vernietig.

Hierdie beperkte verklaring van hierdie frase van artikel 36 is uiters belangrik vir die korrekte vertolking van die ander frases wat deel van die betrokke groep uitmaak. Daar is goeie Bybelse gronde daarvoor dat die satan agter alle afgodediens sit (1 Kor 10:20). Hierdie frases fokus egter nie op die feit dat die ryk van die antichris in die algemeen uitgeroei moet word nie. Hierdie frase dui spesifiek op die ryk van die algemeen uitgeroei moet word nie. Hierdie frase dui spesifiek op die ryk van die antichris veral in sover as wat die ryk binne die Roomse Kerk tot vergestalting gekom het. Gevolglik word die owerhede in hierdie frase slegs opgeroep om die ryk en nié in sover dit in die wêreld in die algemeen voorkom nie.'

12.Die bedoeling is nie hier dat die kerk afgodsdienaars wetlik moet vervolg nie. Die kerk moet afgodsdienaars met die Evangelie benader. 


\section{Veranderinge in die omstandighede waarbinne artikel 36 toegepas moet word}

Die toepasbaarheid van artikel 36 word egter nie alleen geraak deur die verandering aan die teks nie, maar ook deur 'n meervoudige verandering in die omstandighede waarbinne die artikel toegepas moet word. Sedert die aanvaarding van die NGB het meervoudige verskuiwinge in die verhouding tussen kerk en staat plaasgevind..$^{13}$ Soos hierbo beskryf, is die NGB opgestel in 'n era waarin daar in Katolieke Europa oorbeweeg is van 'n situasie waarin daar een (ware) godsdiens (Christelik) en een kerk (RoomsKatoliek) was na 'n situasie waarin meer groepe (Protestants en Rooms-Katoliek) met mekaar meegeding het om as die egte vorm van die (ware) godsdiens aanvaar te word. Weens die eeue oue, hegte verhouding wat kerk en owerheid gehad het, het beide groepe daarop aanspraak gemaak dat die owerheid hulle moes ondersteun, ook met geweld. Soos aangetoon het Gereformeerdes op 'n stadium selfs gemeen om in artikel 36 te bely dat die owerheid 'n Godgegewe taak het om alle afgodery en valse godsdiens te beveg. Hoewel die Christendom tans steeds die dominante geloof in Suid-Afrika is, word die Christendom egter nie in juridiese sin in die grondwet as die enigste (ware) godsdiens erken of verskans nie en kan elkeen op godsdiensvryheid en gepaardgaande owerheidsbeskerming aanspraak maak. Waar die NGB dus opgestel is in 'n era toe daar oorgegaan is van een godsdiens met een kerk na een godsdiens met verskeie kerke, is daar tans verskeie godsdienste in Suid-Afrika wat elkeen wetlike beskerming onder die Handves van Menseregte geniet. ${ }^{14}$

\section{Owerhede moet elkeen se reg op godsdiensvryheid beskerm en uitbou}

Artikel 15 van die Suid-Afrikaanse grondwet beskerm natuurlike sowel as regspersone se reg op die vryheid van gewete, godsdiens, denke, oortuiging en mening (Malherbe 2008:267; Devenish 1999:182). Die artikel bied wye beskerming aan elke mens se innerlike oortuiginge, godsdienstig sowel as sekulêr. Die artikel rig egter nie 'n 'ondeurdringbare muur tussen kerk en staat' op soos wat in Amerika die geval is nie. ${ }^{15}$ Waar artikel 15(1) die breedste moontlike waarborg vir godsdiensvryheid wil bied, en verwag dat die owerhede dit sal respekteer, belig artikel 15(2) 'n bepaalde aspek van hierdie reg en beskerm hierdie bepaling godsdienstige aktiwiteite by staats- of staatsondersteunde instellings soos skole, hospitale en gevangenisse. Die uitoefening van hierdie reg word egter deur drie sub-bepalings 15(1-3) beperk, sowel as deur onder meer artikel 36 van die grondwet (Muller 2010:278, 294).

13. Behalwe vir hierdie verskuiwinge was daar ook verskeie ander wat die ingesteldheid van die mensdom sedertdien beïnvloed, byvoorbeeld die koms van die Verligting en gepaardgaande sekularisme, die groeiende impak van wetenskap en tegniek, globalisasie. Die fokus val hier egter op die verhouding tussen kerk en staat.

14.Vergelyk Muller (2010:276-294) vir 'n uiteensetting van die reg op die vrye beoefening van godsdiens binne die Suid-Afrikaanse konstitusionele demokratiese bestel.

15.Van der Schyff (2001:63) verwys hier na verskeie bronne. Vergelyk ook Malherbe (2006:189) en Venter (2007:1206).
In die lig van artikel 15 het die owerheid dus die plig om rekening te hou met elkeen se reg: op gelyke behandeling deur die owerheid; op outonomie in godsdienstige sake (in sover dit nie met die grondwet bots nie); om eie sake te reguleer, ${ }^{16}$ op waardigheid; op politieke aktiwiteite en finansiële sake (Muller 2010:282). Hierdie bepalinge maak dit onmoontlik vir 'n owerheid om wetlik in te meng waar hy sou meen dat iemand byvoorbeeld ' $n$ valse godsdiens bedryf.

Artikel 15 verplig die owerheid ook om elkeen se vryheid van keuse te respekteer. ${ }^{17}$ Binne die oop en demokratiese samelewing wat die grondwet daar wil stel, speel die reg om keuses wat in ooreenstemming met ' $n$ mens se gewete is vryelik te kan uitoefen, 'n deurslaggewende rol. Hiermee kan elkeen boonop sy identiteit vorm en uitbou en die owerheid het die plig om die reg daartoe te beskerm en uit te bou. Die reg om die godsdiens van jou keuse vryelik te kan aanhang, is een van dié belangrikste elemente van godsdiensvryheid (Van der Schyff 2001:119). Hierdie keusereg geld nie net vir die keuse van 'n bepaalde godsdiens nie, maar ook ten opsigte van die keuse van 'n bepaalde stroming, denominasie of selfs spesifieke gemeente. Volgens Fourie (2006:164) het godsdiensvryheid juis die beskerming van godsdiensdiversiteit in die oog. Die reg op die vryheid van keuse sluit ook die reg in op: die vryheid van verkondiging en beswaar; op onderhouding ('observance'), om volgens eie oortuiging te aanbid; rituele uit te voer; rusdae te onderhou; 'n bepaalde dieet te volg en sekere klere te dra. Die reg op godsdiensvryheid vereis ook dat die owerhede elkeen se reg op godsdienstige opvoeding en onderrig respekteer en sal uitbou. Let egter daarop dat al hierdie regte beperkbaar is (vgl. Muller 2010:295).

In hierdie lig gesien is dit duidelik dat die omstandighede waarin die NGB in 1561 opgestel is, ietwat verskil van dié waarin dit in 1619 as belydenisskrif aanvaar is en drasties verskil van die huidige omstandighede waarbinne dit toegepas moet word, veral in sover dit die owerheid se verhouding tot godsdiens binne 'n konstitusionele demokrasie betref.

\section{Owerhede se ingesteldheid met betrekking tot Godsdiens}

Die juridiese verhouding waarin die owerheid en godsdienstige instansies tot mekaar staan, kan in terme van ' $n$ aantal bekende modelle uitgedruk word. Vorster (2004:198) onderskei vier sodanige modelle om die plek van die godsdienstige strukture binne 'n staat aan te dui:

- die staatsgodsdiensmodel

- die godsdiensstaatmodel

16. Hierdie reg sluit onder meer in dat elkeen sy eie leer vry van inmenging deur die owerheid en howe kan reguleer (vgl. Malherbe 2008:268; Coertzen 2008b:61), sy leer in belydenisdokumente kan verwoord, self amspdraers kan aanwys en self die riglyne daarvoor kan vasstel, 'n eie organisasie tot stand kan bring, onderhou en organiseer, self riglyne vir lidmaatskap, dissipline en die aanstel van werknemers daar kan stel.

17.In die saak Christian Education South Africa v Minister of Education het regter Liebenberg bevind dat 'n hof nie 'n uitspraak oor die 'aanvaarbaarheid, logika konsistensie of volledigheid' van geloofsoortuiginge mag maak nie (Van der Schyff 2001:99). In die lig hiervan wys Van der Schyff daarop dat 'n hof nie 'n uitspraak 2001:99). In die lig hiervan wys Van der Schyff daarop dat ' $n$ hof nie ' $n$ uitspraak
mag maak oor watter godsdiens of denominasie waar en eg is of bo ' $n$ ander oortuiging verkies moet word nie. 
- die geskeide-vyandskapsmodel ('Hostile separation model') en

- die geheel-geskeide-model ('Separation model').

Coertzen (2008a:227) meen dat daar binne laasgenoemde model ook tussen 'n Christelik-geskeide model en 'n sekulêrgeskeide model onderskei moet word.

In die lig van die inhoud van NGB artikel 36 is dit vir hierdie bydrae noodsaaklik om ook vanuit 'n teologies-etiese oogpunt vas te stel watter ingesteldheid owerhede verkieslik behoort in te neem teenoor godsdiens in die algemeen, teenoor die Christendom in besonder en selfs meer spesifiek ten opsigte van die Reformatoriese tradisie. Vorster (2010:162) beskryf hierdie ingesteldheid aan die hand van vyf gestaltes.

\section{Die aktief-teokratiese opsie}

Voorbeelde van hierdie opsie is: die Romeinse ryk; die corpus Christianum onder beheer van die pous; Genève in die era van Calvyn; die Anabaptiste wat God se koninkryk met geweld wou vestig, soos te Münster; en sekere van die huidige Moslemstate wat die Shari'a toepas.

Vorster (2010:164, 2007:158) wys daarop dat hierdie opsie vir lang tye gewild was binne die Reformatoriese tradisie. Hy spreek egter ook skerp immanente kritiek op die opsie uit. Hoewel sy kritiek geldig is, laat hy myns insiens die onderskeid tussen die ware en valse godsdiens, asook die egte en valse vorme van die ware godsdiens, ${ }^{18}$ buite rekening deurdat hy byvoorbeeld sekere Moslemstate onder hierdie opsie insluit. Sulke state behoort gevolglik, tesame met die Romeinse Ryk wat Vorster ook hier indeel, eerder as aktiefpseudoteokraties geklassifiseer te word.

\section{Die aktiewe staatsgodsdiens opsie}

Hier dien Engeland, waar die koningin as staatshoof ook die hoof van die kerk is, as voorbeeld. Volgens hierdie opsie, wat in werklikheid op ' $n$ minder rigiede teokrasie neerkom, gee die owerheid voorkeur aan 'n sekere godsdiens en/of tradisie wat aktief bevorder word. Ander godsdienste en/ of tradisies word nie verbied nie, maar in praktyk deur die owerheid geïgnoreer en verwaarloos.

Vorster (2010:166) lewer ook verskeie punte van geldige kritiek. Hy meen onder meer verder dat hierdie opsie nalaat om die reël 'doen aan ander soos wat jy aan jouself gedoen wil hê' na te kom, een van die fundamentele beginsels van 'n 'sosiale kontrak'. Die vraag is egter wat iemand aan homself gedoen wil hê. Wil die persoon byvoorbeeld hê dat ander hom moet toelaat om die godsdiens van sy keuse te bedryf? Of wil die persoon slegs hê dat ander hom moet toelaat om die ware God op ' $n$ egte wyse te dien? In laasgenoemde geval sou

18.Daar sou geredeneer kon word dat ' $n$ 'valse vorm van die ware godsdiens' ipso facto op 'n valse godsdiens neerkom. NGB artikel 29 onderskei egter enersyds tussen die ware en valse kerk, terwyl dit die valse kerk steeds kerk noem. Ek

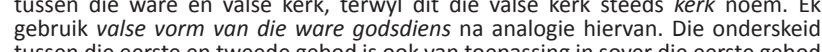
tussen die eerste en tweede gebod is ook van toepassing in sover die eerste gebo betre op die wyse daarvan (De Bruyn 2002:51). 'n Persoon wat die eerste gebod hou en die tweede oortree, aanbid die ware God, maar op die verkeerde (valse) wyse en bedryf dus die ware godsdiens op 'n valse wyse. die persoon dus kon sê: 'Ek wil hê dat jy my moet toelaat om die ware God en Hom alleen te dien en ek sal jou dit eweneens ook toelaat.' 'n Persoon wat só redeneer, voldoen ook aan die vereiste om aan ander te doen soos wat hy aan homself gedoen wil hê. In sover as wat iemand die vereiste soos in die eerste geval verwoord, is Vorster se kritiek geldig. Sy kritiek is egter ongeldig vir die geval waar 'n persoon die vereiste stel soos in die tweede geval verwoord. Die mate waarin 'n persoon die Here en sy eise ken en die Bybelse beginsel van toerekeningsvatbaarheid in ag neem, sal deels bepaal wat hy aan homself gedoen wil hê. Soos hierbo aangetoon hou Vorster in sy definisie van teokrasie rekening met die juridiese sfeer (waarbinne die onderskeid tussen die ware en valse godsdiens nie getref word nie).

\section{Die aktief-neutrale opsie}

Die VSA en Frankryk dien hier as voorbeelde. In hierdie lande word godsdiens in werklikheid toenemend uit die openbare lewe verdring. Die openbare simbole wat 'n godsdienstige oorsprong het, word as 'blote seremoniële-deïsme' beskou.

As deel van die kritiek vermeld Vorster die Franse verbod op die dra van 'n hijab en die vertoon van kruise in skole as 'n ekstreme voorbeeld van hierdie opsie. Die opsie faal daarin dat dit die omvattende aard van godsdiens (wat nie tot die private gerangeer kan word nie) in die naam van neutraliteit ignoreer. Die gevolg is dat sekularisme, wat in wese ook 'n godsdiens is, toenemend die openbare terrein oorheers en ander godsdienste verdring (vgl. Vorster 2010:168).

\section{Die aktief-universalistiese opsie}

Indië en Namibië dien hier as voorbeelde. Hierdie opsie beklemtoon dat daar in elke godsdiens iets van waarde is. Hoewel hierdie opsie neutraal voorkom, bevorder dit in werklikheid 'n inter-religie ('n besondere vorm van sekularisme) ten koste van alle ander godsdienste. Onder leiding van Kader Asmal, toenmalige minister van opvoeding, het hierdie opsie ook neerslag gevind in die SuidAfrikaanse onderwysbeleid (Vorster 2010:170).

\section{Die aktief-plurale opsie}

Hoewel Vorster nie 'n voorbeeld noem van 'n land waar hy meen hierdie opsie toegepas word nie, wys hy daarop dat 'n owerheid wat hierdie opsie verkies, die teenoorgestelde houding inneem as een wat die aktief-universalistiese opsie voorstaan. Myns insiens sou die aktief-universalistiese opsie ook die aktief-pluralistiese opsie genoem kon word omdat hierdie opsie nie alleen van die verskeidenheid van godsdienste uitgaan nie, maar ook van hulle prinsipiële gelykheid. Hierteenoor wil die aktief-plurale opsie wel met die verskeidenheid van godsdienste rekening hou, sonder om 'n waardeoordeel oor elkeen te fel.

In teenstelling met die aktief-neutrale opsie, wil die aktiefplurale opsie daarmee rekening hou dat godsdiens in werklikheid nie uit die openbare terrein verban kan word nie (vgl. Van der Walt 2005:56). Waar pogings om 'n spesifieke 
godsdiens of tradisie te bevoordeel, huigelary in die hand werk, lei pogings om godsdiens uit die openbare terrein te verban daartoe dat sekularisme sy greep op die samelewing versterk en dat 'n samelewing se morele waardes vervlak.

Vorster (2010:172) verskaf voorbeelde van hoe hierdie opsie in die praktyk kan funksioneer: 'n openbare geleentheid, soos die opening van die parlement, begin met 'n godsdiensoefening waartydens die betrokke persone óf in hulle onderskeie groepe verdeel, óf saam vergader en 'n verteenwoordiger van elke godsdiens geleentheid kry om die leiding te neem. Niemand moet egter enigsins verplig word om aan enige iets wat in stryd met sy gewete of geloof is, deel te neem nie. Agnostici kan heeltemal van sulke geleenthede verskoon word.

Die vraag is vervolgens hoe daar in die lig van NGB artikel 36 oor die verskillende opsies geoordeel moet word en met watter opsie(s) die artikel vereenselwig kan word.

\section{Die mees geskikte opsie}

Soos vermeld is die NGB (1561) opgestel in die era waarin die Europese corpus Christianum as godsdiensstaat besig was om te verbrokkel. Teen die tyd dat die NGB in 1619 finaal as belydenisskrif aanvaar is, was daar in werklikheid reeds 'n staatsgodsdiensmodel in die Nederlande in werking (Muller 2010:23). Aangesien artikel 36 van die NGB daarvan uitgaan dat die gereformeerde vorm van die Christendom die egte vorm van die ware godsdiens verteenwoordig, sou die NGB binne albei die modelle (die aktief-teokratiese of aktiewe staatsgodsdiens opsies) toegepas kon word in sover die gereformeerde godsdiens die voorkeur geniet.

Aangesien artikel36'n aktiewe rol vir die owerheid ten opsigte van die (gereformeerde) godsdiens sowel as 'n openbare rol vir die (gereformeerde) godsdiens op sigself sien, sou die artikel beswaarlik versoenbaar wees met die aktief-neutrale of die aktief-universalistiese opsie. In die lig van die kritiek op die aktief-teokratiese, aktiewe staatsgodsdiens, aktiefneutrale en aktief-universalistiese opsies, verteenwoordig nie een van hierdie opsies die houding wat owerhede, eties gesproke, verkieslik ten opsigte van godsdiens moet inneem nie.

Die vraag is gevolglik of artikel 36 ook met die aktiefplurale opsie versoenbaar sou wees en hoe wenslik hierdie opsie as sodanig is? Ek wil betoog dat artikel 36 inderdaad met hierdie opsie versoenbaar is veral sedert die take wat voorheen (skynbaar) op die owerheid gelê is, uitdruklik as doelstellings geformuleer is. Soos aangetoon, word daar nie (meer) in artikel 36 van die owerhede verwag om (enige vorm van) afgodery direk of indirek te beveg nie en ook nie om die Woord self (of deur middel van die kerk) 'orals te laat verkondig' nie. (Indien die owerheid inderdaad sodanige take sou gehad het, sou dit in werklikheid slegs binne die aktief-teokratiese of aktiewe staatsgodsdiens modelle tot uitvoer gebring kon word.) Dit is bowendien ook aangetoon dat aktiewe staatsondersteuning, vanuit 'n teologies- etiese oogpunt gesien, normaalweg onwenslik is aangesien sodanige ondersteuning huigelary en uiteindelik selfs valse godsdiens in die hand werk (vgl. ook Van der Walt 2005:64).

\section{Die toepasbaarheid van die aktief-plurale opsie}

Artikel 36 stel dit egter (steeds) dat die owerheid die Woordbediening moet beskerm. Kernagtig gestel kom hierdie opdrag daarop neer dat die owerhede so sal regeer dat daar ruimte is vir die Woord om bedien te word. Vorster se uiteensetting van die aktief-plurale opsie toon dat hierdie opsie die owerheid in staat stel om hierdie plig na te kan kom. Van der Schyff (2001:71) se mening dat die owerheid die taak het om omstandighede te skep waarbinne godsdiensvryheid kan blom, sluit hierby aan (vgl. ook Muller 2010:280). Die grondwet verplig owerhede immers om die regte van die burgers nie alleen te beskerm nie, maar daadwerklik uit te bou. Vervolgens het owerhede dus die plig om die openbare terrein vir almal ewe toeganklik te hou. Dit is egter die aanhangers van 'n godsdiens se reg en plig om hulle godsdiens (op die openbare terrein) te beoefen en nie die owerhede s'n nie. ${ }^{19}$

Hierdie opsie lei vervolgens ook nie daartoe dat daar van die owerheid vereis word om ' $n$ keuse tussen die ware en valse godsdiens en/of tradisie te maak nie, iets wat 'n owerheid vanuit ' $n$ juridiese oogpunt gesien nie in staat is om te doen nie. Indien die owerheid in die lig van artikel 36 inderdaad opgeroep is om valse godsdienste (self, aktief) te bestry, sou dit vereis het dat die owerheid hierdie keuse moes maak om te kon weet watter godsdienste en/of tradisies beveg moes word. In so 'n geval sou die aktief-plurale opsie, in die lig van artikel 36, onaanvaarbaar gewees het. (Aangesien 'n owerheid na regte nie die keuse tussen die ware en valse godsdiens en/of tradisie kan fel nie, is dit in die lig van artikel 36 noodsaaklik dat 'n owerheid ook nie sal redeneer dat hy om hierdie rede geen godsdiens toelaat (aktief-neutrale opsie) of alle godsdienste bevoordeel (aktief-universele opsie) nie. In hierdie terme gestel wil die aktief-plurale opsie alle godsdienste toelaat en geeneen bevoordeel nie.)

Hoewel artikel 36 die owerheid dus nie as dienaar van die kerk wil inspan nie, sien artikel 36 die owerheid egter steeds

19.My betoog is dus nie dat verskillende godsdienstige groepe, waaronder byvoorbeeld animiste en Moslems, aangemoedig moet word om byvoorbeeld aan die opening van die nasionale parlement deel te neem nie, maar dat sulke groep

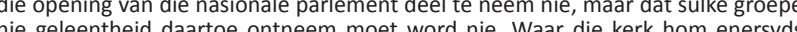
nie geleentheid daartoe ontneem moet word nie. Waar die kerk hom enersyds van onregverdige diskriminasie of die owerheid se ondersteuning daarvan moet weerhou, moet hy andersyds ook teen die skyn daarvan waak. Dit is juis die (nieChristen) mense wat sou voel dat daar onregverdig teen hulle gediskrimineer word n hulle dus teenoor die Christelike geloof sou verhard, wat tot die eer van God vir sy koninkryk gewen moet word. Daar kan boonop nie van 'n heiden verwag word om, solank as wat hy 'n heiden is, te besef of te aanvaar dat die Christelike geloof (en in terme van art. 36, boonop ook nog die Gereformeerde vorm daarvan) die enigste ware geloof is en dus bevoordeel behoort te word nie. Indien slegs Christene toegelaat sou word om die parlement te open, sal dit boonop soos aangetoon huigelary en valse godsdiens bevorder en die koninkryk van God skaad. Verder sou die vraag in so geval ook wees op grond van watter maatstaf die owerheid sou besluit watter persone vir die taak kwalifiseer. In hierdie proses sal amptenare' $n$ oordeel moet fel sonder dat hulle noodwendig die nodige 'Geestelike kapasiteit' het (vgl. 1 Kor 12:3b). Dieselfde dilemma kom ook voor indien burgers wat die Christelike geloof openlik teenstaan, verbied sou word om tot die owerheid wat die Christelike geloof openlik teenstaan, verbied sou word om tot die owerheid verkies te word. (As gevolg van hierdie dilemmas is daar skrywers wat meen dat artikel 36 noodwendig ' $n$ staatskerk veronderstel waarin hierdie kerk dan die keuring namens die owerheid doen. Dit is egter reeds hierbo aangetoon waarom $\mathrm{o}$ ' $\mathrm{n}$ opsie nie werklik wenslik is nie.) Die Here nie die owerheid nie) op om die Evangelie aan elkeen, ook die persone wat teen die Christelike geloof gekant is, te verkondig om élkeen sodoende deur die krag van die Gees van die unieke waarheid van die Evangelie te oortuig. 
as medewerker in die koninkryk van die Here Jesus Christus, ' $n$ medewerker van sy kerk. Ofskoon artikel 36 die owerheid dan ook nie die taak opdra om die ryk van die antichris te vernietig ensovoorts nie, eis artikel 36 dat die owerheid hiertoe sal meewerk binne die Koninkryk. Die derde sin (in die oorspronklike teks) van artikel 36, wat die taak van die owerheid verwoord, eindig immers onbestrede met 'sodat God deur elkeen geëer en gedien word soos Hy in sy Woord

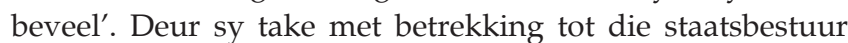
en die beskerming van die Woordbediening uit te voer, kan die owerheid selfs binne ' $n$ aktief-plurale opsie meewerk ter bereiking van hierdie oorkoepelende doelstelling.

Indien owerhede die aktief-plurale opsie as uitgangspunt neem, sal dit (meer) kontak tussen mense van verskillende godsdienste tot gevolg hê. Vanuit 'n teologies-etiese oogpunt kan hierdie kontak in twee opsigte beoordeel word. Eerstens behoort die kerk geleenthede aan te gryp om die Evangelie aan almal te verkondig (vgl. ook die laaste frase van die derde sin van die oorspronklike teks). Hoewel so 'n situasie die vloei van inligting tussen godsdienste en wedersydse begrip vir mekaar sal verbeter, hoef 'n ware Christen wie se geloof ' $n$ gawe van God is, nie sodanige kontak te vrees nie (vgl. 2 Tim 1:7). Weens die soewereiniteit van God hoef die Christelike geloof allermins terug te deins vir 'n situasie waarin godsdienstige oortuigings in konflik kom en dit as't ware neerkom op 'n oorlewing van die sterkste. Volgens Witte (2007:170) het Althusius al daarop gewys dat wanneer die owerheid die natuurlike vryheid van elke mens se gewete gerespekteer het, dit nie 'n gevaar vir die Christelike geloof was nie, maar juis ' $n$ bevestiging van die oortuigingskrag en egtheid daarvan. Witte (2007:239) wys ook op die standpunt van John Milton waarvolgens die Christelike geloof nie wette nodig het om te oorleef nie en die kerk ook nie die staat nodig het om te blom nie. Milton het ook gemeen dat Konstantyn die Christendom al mislei het om te glo dat wettiging van die Christelike geloof ('the establishment of Christianity by law') asook die staatlike beheer oor en onderhoud van die kerk, die voorspoed van sowel die kerk as die staat sal verseker. Artikel 15 van die grondwet beskerm boonop ouers se reg om hulle kinders volgens hulle geloofsoortuiginge op te voed en om dit selfs van openbare skole te verwag (Malherbe 2008:269). Kinders wat nog nie in die geloof gevestig is nie, hoef dus nie blootgestel te word aan 'n situasie waarbinne godsdienstige oortuigings in konflik kom nie.

\section{Verdere teologies-etiese beoordeling van die aktief-plurale opsie}

Die aktief-plurale opsie is voorts ook op verdere gronde aanvaarbaar vanuit 'n teologies-etiese oogpunt. In Matteus 13 vertel Jesus sewe opeenvolgende gelykenisse. Hierdie gelykenisse het betrekking op die reeds-en-nog-nie tydperk tussen sy koms en wederkoms. Jesus fokus hier op die verkondiging van die Evangelie en die groei van sy kerk te midde van die koms van sy koninkryk. Met die gelykenis van die saaier wys Jesus onder meer daarop dat die Woord aan almal sonder onderskeid verkondig sal word. 'n Saaier saai die saad immers nie net op die plekke wat mettertyd sou blyk die ideale plekke te wees nie (vgl. die term orals in NGB 1992:514 [art. 36]). Hierna vertel Jesus die gelykenis van die onkruid wat deur ' $n$ vyand tussen 'n boer se koring gesaai is (Matt 13:24-30). Jesus beklemtoon hier dat die koring en die onkruid ook toegelaat moet word om tot en met sy wederkoms saam te groei (vgl. vers 30). Dit is verkieslik bo 'n benadering waarin die arbeiders die onkruid probeer verwyder of die hele land omdolwe om van onkruid wat die bose gesaai het, ontslae te raak (vgl. MacArthur 1985:32, 50).

Die aktief-plurale opsie kan op 'n beter wyse as die ander vier opsies rekening hou met die tweevoudige verandering wat sedert die opstel van die NGB plaasgevind het. Soos aangetoon is die NGB opgestel toe daar tydens die Reformasie oorgegaan is van 'n samelewing van een godsdiens met een kerk, na 'n samelewing van een godsdiens met 'n veelheid van kerke. (Dit is waarom dit nodig geword het om in NGB art. 29 te bely watter kerk die ware kerk van die Christelike godsdiens is.) Tans is daar nie alleen 'n multi-kerklike opset in Suid-Afrika nie, maar ook 'n multi-godsdienstige opset. Voor die Reformasie was daar dus een godsdiens met een kerk. Tydens en kort daarna was daar een godsdiens met verskeie kerke. Tans is daar verskeie godsdienste. Waar die NGB opgestel is om vir die eerste verandering voorsiening te maak, moet die opsie wat tans verkies word vir die tweede verandering ook voorsiening maak. Van die vyf genoemde opsies is die aktief-plurale opsie die mees geskikte hiervoor.

\section{'n Uitspraak van president Jacob Zuma}

In die media is verslag gelewer dat president Jacob Zuma tydens die naweek van 5 en 6 Februarie 2011 op 'n politieke saamtrek onder meer gesê het dat 'n ANC-lidmaatskapkaart toegang tot die hemel verseker (Edwards \& Azzakani 2011). Hierdie voorval het tot wye veroordeling gelei en is deur die Suid-Afrikaanse Raad van Kerke, verskeie kerkverbande en politieke partye gekritiseer (Anon a 2011). Die klagtes was onder meer dat godsdiens nou vir politieke doelwitte gebruik word en dat sy uitsprake lasterlik of minstens ligsinnig was. Daar was ook (misplaasde) uitsprake dat Zuma hiermee 'die beginsel van skeiding van kerk en staat' aangetas het. In reaksie op die klagtes het die ANC Zuma se optrede verdedig op grond van sy reg op vryheid van spraak (Anon b 2011).

Die vraag is vervolgens hoe hierdie voorval beoordeel moet word in die lig van die toepassing van NGB artikel 36. Die ANC moet enersyds gelyk gegee word dat Zuma reg op die vryheid van spraak het. Hoewel die reg hierop in die grondwet beperk word, het die uitspraak geen landswet oortree nie. Daar is byvoorbeeld (tereg) geen wet teen godslastering nie. ${ }^{20}$ (Indien art. 36 nog na sy pre-1982 weergawe geïnterpreteer is, sou daar egter geëis kon word dat die owerheid wetlik teen Zuma moes optree omdat hy dwaalleer verkondig het wat valse godsdiens bevorder.) In die lig van artikel 36 is die vraag egter nie alleen of Zuma in terme van die grondwet die rég gehad het om hierdie uitsprake te maak nie, maar ook of die uitsprake éties verantwoordbaar is. In die lig van

20.Vergelyk Muller (2010:284) se bespreking van die Konstitusionele Hof se uitspraak in hierdie verband. 
die Evangelie (vgl. onder meer Rom 3:21, 22; NGB 1992:502 [art. 23]) is die antwoord ' $n$ besliste: 'Nee'. Hierdie uitspraak bevorder allermins die koninkryk van Jesus Christus en die verspreiding van die Evangelie (vgl. art. 36). Juridiese aanvaarbaarheid waarborg nie etiese aanvaarbaarheid nie. Hoewel die owerheid gevolglik nie die taak het om Zuma te vervolg nie, het die kerk die taak om die Woord aan hom te verkondig om hom hierdeur tot ander insigte te bring.

\section{Gevolgtrekking}

Van die vyf modelle wat geïdentifiseer is om die ingesteldheid van owerhede ten opsigte van godsdiens aan te dui, is die aktief-plurale opsie nie alleen die geskikste vir die toepassing van NGB artikel 36 nie, maar op sigself inderdaad uitnemend geskik om hierdie artikel toe te pas op 'n wyse wat getrou is aan die hart van die NGB en in besonder die Evangelie in geheel.

Hiermee meen ek dus ook dat prof. J.M. Vorster met sy analise van die verskillende opsies, asook sy keuse vir die aktief-plurale opsie 'n bydra lewer tot die uitbou van die Reformatoriese tradisie.

\section{Erkenning \\ Mededingende belange}

Die outeur verklaar dat hy geen finansiële of persoonlike verbintenis het met enige party wat hom nadelig kon beïnvloed in die skryf van hierdie artikel nie.

\section{Literatuurverwysings}

Anon a., 2011, 'SACC takes issue with Zuma "blasphemy"', News24, viewed 07 February

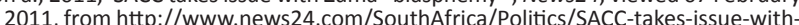
Zuma-blasphemy-20110207

Anon b., 2011, 'Zuma's comments not blasphemous - ANC', News24, 06 February, viewed 7 February 2011, from http://www.news24.com/SouthAfrica/Politics/ viewed 7 February 2011, from http://WWW.news

Ban Ki-Moon., 2008, Secretary-general deeply saddend by inter-communal violence in Nigeria, encouraged by efforts to restore normalcy, United Nations Department of Public Information, New York, viewed 20 February 2011, from http://www. un.org/News/Press/docs/2008/sgsm11975.doc.htm

Bredenkamp, F., 1996, 'Elemente van die staat: Burgers en burgerskap', in M Wiechers \& F. Bredenkamp (reds.), Die staat: Teorie en praktyk, bl. 97-138, Van Schaik, Pretoria.

Calvyn, J., 1992, Institusie van die Christelike godsdiens 1559, Boek IV, vertl. H.W. Simpson, Calvyn Jubileum Boekefonds, Potchefstroom.

Calvyn, J., 1988, Institusie van die Christelike godsdiens 1559, Boek III, transl. H.W. Simpson, pp. 699-1264, Calvyn Jubileum Boekefonds, Potchefstroom.

Christian Reformed Church of North America, 2011, Christian Reformed Church beliefs: The Belgic Confession, viewed 25 February 2011, from http://www.crcna. org/pages/belgic_articles33_37.cfm\#

Cloete, G.J., 1986, 'Die kerkbegrip van die Nederlandse Geloofsbelydenis', D. DivProefskrif, Universiteit van Pretoria, Afdeling B, Pretoria.

Coertzen, P., 2008a, 'The relationship between church and state in a democracy with guaranteed freedom of religion' [Die verhouding tussen kerk en staat in ' $n$ demokrasie met gewaarborgde godsdiensvryheid], Nederduitsch Gereformeerde Teologiese Tydskrif 49(1\&2), 221-231.

Coertzen, P., 2008b, 'Being church and the freedom of religion - the function and ambit of religious freedom' [Kerkwees en godsdiensvryheid - die funksie en omvang van godsdiensvryheid], Nederduitsch Gereformeerde Teologiese Tydskrif $49(3 \& 4), 60-68$

De Bruyn, P.J., 2002, The ten commandments, transl. F. Krüger. PU vir $\mathrm{CHO}$ Potchefstroom.

Devenish, G.E., 1999, A commentary on the South African Bill of Rights, Butterworths, Durban.

De Groot, D. J., 1955, De reformatie en de staatkunde, T. Wever, Franeker.

De Jong, O.J., 1980, Geschiedenis der kerk: tiende, geheel nuwe druk naar het gelijknamige boek van dr. H. Berkhof, G.F. Callenbach N.V. Uitgeverij, Nijkerk.
De Jong, O.J., 1987, Geschiedenis der kerk: Elfde, bijgewerkte druk, G.F. Callenbach N.V. Uitgeverij, Nijkerk.

Doekes, L., 1975, Credo: Handboek voor de gereformeerde symboliek, Ton Bolland, Amsterdam.

Edwards, G. \& Azzakani, R., 2011, 'ANC kaartjie na die hemel', Nuus24, besigtig op 07 Februarie 2011, by http://www.nuus24.com/Suid-Afrika/Nuus/ANC-kaartjiena-hemel-20110207

Fourie, P., 2006, 'Godsdiensvryheid in die ban van NGB Art 36 - seën of vloek?' Nederduitsch Gereformeerde Teologiese Tydskrif 47(1\&2), 158-172.

Free Church of Scotland, 2011, Confessions \& catechisms: The Belgic Confession of faith 1619, viewed 24 February 2011, from http://www.freechurch.org/index. $\mathrm{php} /$ scotland/resources-article/the_belgic_confession_of_faith/

Gereformeerde Kerke in Suid-Afrika (GKSA), 1910, Handelingen van de zestiende algemene synodale vergadering van de Gereformeerde Gemeenten van ZuidAfrika, N.D. van der Reyden, Pretoria.

Gereformeerde Kerke in Suid-Afrika (GKSA), 1973, Handelinge van die agt-en-dertigste sinodale vergadering van die Gereformeerde Kerk in Suid-Afrika, Potchefstroom Herald, Potchefstroom.

Gereformeerde Kerke in Suid-Afrika (GKSA), 1979, Handelinge van die veertigste sinode van die Gereformeerde Kerk in Suid-Afrika, Potchefstroom Herald, Potchefstroom.

Gereformeerde Kerke in Suid-Afrika (GKSA), 1982, Handelinge van die een-enveertigste sinode, Potchefstroom Herald, Potchefstroom.

Gereformeerde Kerke in Suid-Afrika (GKSA), 2009, Handelinge van die vyftigste nasionale sinode en die tiende sinode Middellande in die eerste algemene sinode te Potchefstroom op 5 Januarie 2009 en volgende dae, V \& R Drukkery, Pretoria.

Grim, B.J., 2010, 'Global restrictions on religion: A 2010 summary' [Wêreldwye beperkings op godsdiens: 'n 2010-opsomming], International Journal of Religious Freedom 3(1), 39-46, viewed 23 February 2011, from http://journals.sabinet.co.za. nwulib.nwu.ac.za/WebZ/images/ejour/ijrf/ijrf_v3_n1_a6.pdf?sessionid=01 59511-770625497\&format=F

Heyns, J.A., 1992, Inleiding tot die dogmatiek: Aan die hand van die Nederlandse Geloofsbelydenis, NG Kerkboekhandel-Uitgewers, Halfway House.

Jonker, W.D., 1994, Bevrydende waarheid: Die karakter van die gereformeerde belydenis, Hugenote Uitgewers, Wellington.

Kurtz, J.H., 1904, Leerboek der Kerkgeschiedenis: Naar de laatste Hoogduitse uitgawe, voor Nederland bewerkt, transl. J.A.G. van Wijk, Kemink, Utrecht.

Latourette, K.S., 1953, A History of Christianity, Harper \& Row, New York.

Laursen, J.C (ed.), 1995, New essays on the political thought of the Huguenots of the refuge, Leiden, Brill, viewed 23 February 2011, from http://books.google.co.za/ books?id=UIYs73HwE7kC

MacArthur, J., 1985, The parables of the kingdom, Moody Press, Chicago.

Malherbe, R., 2006, 'Enkele kwelvrae oor die grondwetlike beskerming van die reg op godsdiensvryheid', Nederduitsch Gereformeerde Teologiese Tydskrif 47(1\&2), 180-199.

Malherbe, R., 2008, 'Die impak van die grondwet op godsdiens - 'n voorlopige waarneming', Nederduitsch Gereformeerde Teologiese Tydskrif 49(1\&2), 263-278.

Muller, D.F., 2010, 'Die roeping van Suid-Afrikaanse owerheid binne die grondwetlike demokrasie in die lig van artikel 36 van die Nederlandse Geloofsbelydenis', PhDproefskrif, Noordwes-Universiteit, Potchefstroom.

Nederlandse Geloofsbelydenis (NGB), 1992, Geloofsbelydenis soos opgestel deur G. De Brès, In Gereformeerde Kerke in Suid-Afrika, Die berymde psalms, belydenisskrifte en liturgie, Calvyn Jubileum Boekefonds, Potchefstroom, pp. 488-516.

Ozyurt, S.S., 2009, Living Islam in Non-Muslim Spaces: How Religiosity of Muslim Immigrant Women Affect Their Cultural and Civic Integration in Western Host Societies, Irvine, University of California, viewed 25 February 2011, from http:// ccis.ucsd.edu/PUBLICATIONS/documents/WP179.pdf

Polman, A.D.R. a, s.a, Onse Nederlandse Geloofsbelydenis, Deel 1, T. Wever, Franeker. Polman, A.D.R. b, s.a., Onse Nederlande Geloofsbelydenis, Deel 4, T. Wever, Franeker.

Sauer, C., 2009, "The religious other as a threat", Religious persecution expressing xenophobia - a global survey of Christian-Muslim convivience' ['Die godsdienstige ander as bedreiging, godsdienstige vervolging wat xenofobie uitdruk -' $n$ globale opname van botsings tussen Christen en Moslem], Missionalia 37(3), 69-89, viewed 25 February 2011, from http://journals.sabinet.co.za.nwulib.nwu.ac.za/ WebZ/images/ejour/mission/mission_v37_n3_a13.pdf?sessionid=01-59385WebZ/images/ejour/mis
460082646\&format $=F$

Scholtz, L., 2011, 'Vergeet vrees vir fundamentaliste?', Beeld, 01 Maart, besigtig op 2 Maart 2011, by http://www.beeld.com/In-Diepte/Nuus/Vergeet-vrees-vir2 Maart 2011, by http://W

Schulze, L.F., 1991, Ons glo met die hart, E.F.J.S, Orkney.

Smiles, J., 2008, 'The root causes of the Darfur conflict' [Die kernoorsake van die Darfoer-konflik], Journal for Contemporary History 33(1), 59-65, viewed 26 February 2011, from http://journals.sabinet.co.za.nwulib.nwu.ac.za/WebZ/ images/ejour/contemp/contemp v33 n1_a4.pdf?sessionid=01-39036images/ejour/conte
585015192\&format $=F$

Strauss, S.A., 1993, 'John Calvin and the Belgic Confession' [Johannes Calvyn en die Belgiese geloofsbelydenis], In die Skriflig 27(4), 501-517.

Van Bruggen, J., 1980, Het Amen der kerk, Ton Bolland, Amsterdam. 
Van der Merwe, D.C.S., 1969, 'Die verandering van artikel 36 van die Nederlandse Geloofbelydenis in Nederland in 1905: Progressie of regressie? Was dit reg en
nodig om Dordt te korrigeer, of kan ons sonder meer daarop voortbou as suiwer nodig om Dordt te korrigeer, of kan ons sonder meer
Skriftuurlike fondament', In die Skriflig 3(11), 1-64.

Van der Schyff, G., 2001, 'The Right to Freedom of Religion in South Africa', LLMSkripsie, RAU, Johannesburg.

Van der Walt, B.J., 2002, The liberating message: A Christian worldview for Africa, Institute for Contemporary Christianity in Africa, Potchefstroom.

Van der Walt, B.J., 2005, 'Godsdiensverskeidenheid, -onverdraagsaamheid en -vryheid, 'n Prinsipiële besinning (1)', In die Skriflig 39(1), 53-79.

Van der Zwaag, K., 1999, 'Onverkort of gekortwiekt?', Artikel 36 van de Nederlandse Geloofsbelijdenis en de spanning tussen overheid en relegie - Een systematieshistorische interpretatie van een 'omstreden' geloofsartikel, Groen, Heerenveen.

Venter, F., 2007, 'Religious plurality: The responsibilities of the constitutional state', Die Ordnung der Freihet: Festschrift für Christian Starck zum siebzigsten Geburtstag, Mohr Siebeck Verlag, Tübingen.

Visscher, H., 1939, De staatkundige beginsellen der Nederlandsche Geloofsbelijdenis in hun schriftuurlijk karakter getoetst en gehandhaafd, Bout Huizen, n.p.
Vonk, C., 1956, De voorzeide leer, Deel 111b, De Nederlandse Geloofsbelijdenis, art. 22-24 en 27-37, Drukkerij Barendrecht, Barendrecht.

Vorster, J.M., 1993, 'Godsdiensvryheid in 'n toekomstige Suid-Afrika in die lig van artikel 36 van die Nederlandse Geloofsbelydenis', In die Skriflig 27(3), 307-321.

Vorster, J.M., 2004, Ethical perspectives on human rights, Potchefstroom Theological Publications, Potchefstroom.

Vorster, J.M., 2007, Christian attitude in the South African Liberal democracy, Potchefstroom Theological Publications, Potchefstroom.

Vorster, J.M., 2010, 'Current option for the constitutional implementation of religious freedom', in A. van de Beek, E.A.J.G. van der Borght \& B.P. Vermeulen (ed.), Freedom of religion, pp. 153-175, Brill, Leiden.

Walker, W., Norris, R.A., Lotz, D.W. \& Handy, R.T., 1997, A History of the christian church, 4th edn., T. \& T. Clark Ltd., Edinburgh.

Witte, J., 2007, The Reformation of rights, Cambridge University Press, Cambridge.

Witte, J., 2009, Separation of church and state - Calvin style: A 500th anniversary celebration, viewed 01 March 2011, from http://vimeo.com/2852459 (Audio and video recording available from author, See $00: 13^{\prime} 20^{\prime}$ ). 